SPACE OF DETENTION 



\section{SPACE OF DETENTION}

THE MAKING OF

A TRANSNATIONAL

GANG CRISIS

BETWEEN LOS ANGELES

ELANA ZILBERG

AND SAN SALVADOR

DUKE UNIVERSITY PRESS Durham and London 2011 
() 2011 Duke University Press

All rights reserved

Printed in the United States

of America on acid-free paper @

Designed by Amy Ruth Buchanan

Typeset in Quadraat by Tseng

Information Systems, Inc.

Library of Congress Cataloging-in-

Publication Data appear on the last

printed page of this book. 
In memory of

Dorene Golin Zilberg,

Alicia Rivas de Baires,

and Begoña Aretxaga 
